\title{
Monthly variation and interrelationship of physicochemical characteristics of a perennial pond at a biological park in Patna, Bihar, India
}

\author{
Sumona Sanyal \\ Department of Zoology, Patna University, Patna, Bihar, India \\ D. K. Paul* \\ Department of Zoology, Patna University, Patna, Bihar, India \\ ${ }^{*}$ Corresponding author. E-mail: dkpaul.pat31@gmail.com
}

\begin{abstract}
The present study was designed to observe the monthly variation and interrelationship among the physicochemical characteristics of the surface water of a perennial pond situated at Biological park also known as Sanjay Gandhi Jaivik Udyan, Patna. The different physicochemical parameters was determined for the period of two years i.e from May, 2016 to April, 2018 to analyse the pond water quality. The maximum value of water temperature, transparency, total solids, total dissolved solids, total suspended solids, turbidity, $\mathrm{pH}$, conductivity, dissolved oxygen, biological oxygen demand, chemical oxygen demand, total alkalinity, chloride, total hardness, calcium hardness, magnesium hardness, nitrate, inorganic phosphorus, sodium, potassium were found as $32.6 \pm 0.24{ }^{\circ} \mathrm{C} ; 24.57 \pm$ $0.18 \mathrm{~cm} ; 1510.66 \pm 4.50 \mathrm{mg} / \mathrm{l} ; 1210 \pm 0.89 \mathrm{mg} / \mathrm{l} ; 478.33 \pm 2.11 \mathrm{mg} / \mathrm{l} ; 37.46 \pm 0.22 \mathrm{NTU}$; $8.54 \pm 0.0245 ; 542 \pm 11.57 \mu \mathrm{S} \mathrm{cm}{ }^{-} 1 ; 8.216 \pm 0.01 \mathrm{mg} / \mathrm{l} ; 6.73 \pm 0.074 ; 14.27 \pm 0.114 \mathrm{mg} /$ I, $269.36 \pm 0.157 \mathrm{mg} / \mathrm{l}, 63.51 \pm 0.13 \mathrm{mg} / \mathrm{l}, 333.33 \pm 2.581 \mathrm{mg} / \mathrm{l} ; 101.2 \pm 0.089 \mathrm{mg} / \mathrm{l} ; 19.13$ $\pm 0.068 \mathrm{mg} / \mathrm{l} ; 1.56 \pm 0.004 \mathrm{mg} / \mathrm{l} ; 1.43 \pm 0.0078 \mathrm{mg} / \mathrm{l} ; 7.726 \pm 0.025 \mathrm{mg} / \mathrm{l}, 4.81 \pm 0.215$ $\mathrm{mg} / \mathrm{l}$ respectively during the study period. This study therefore gives insight about the existing health of the pond and will be helpful to take suitable measure by the authorities to maintain the healthy environment and wholesomeness of the pond.
\end{abstract}

Keywords: Interrelationship, Monthly variation, Physicochemical characteristics, Pond

\section{INTRODUCTION}

Freshwater is a paramount natural resource and a valuable natural asset (Mohan et al., 2013). It is crucial source for the existence of entire living organisms (Smitha et al., 2007). Unrestrained increase in human population and rapid urbanisation in all over the world is placing great stress upon freshwater resources (Bano et al., 2016). In India, most of the freshwater bodies are not only utilized for drinking purposes, fisheries, navigation, aquifer replenishment, recreation, electric power production, and support of biodiversity but are also used as a place to dispose effluents and solid wastes (Barai and Kumar, 2012, Deshmukh, 2012 and Majumder and Dutta, 2014). In India, since times immemorial, ponds are used to conserve and store water. Pond is significant for environment and also essential for ecological community because it supports aquatic biodiversity, has large carbon sequestration capacity, regulates temperature and humidity (microclimate regulation), ground water recharge, rain water harvesting and other beneficial effects such as aquaculture (Kumar and Padhy, 2015).

The physicochemical characteristic indicates the
Article Info

DOI:10.31018/jans.v11i2.2103

Received: April 30, 2019

Revised: June 2, 2019

Accepted: June 8, 2019

\section{How to Cite}

Sanyal, S. and Paul, D.K (2019). Monthly variation and interrelationship of physicochemical characteristics of a perennial pond at a biological park in Patna, Bihar, India. Journal of Applied and Natural Science, 11(2): 492- 502 https://doi.org/10.31018/ jans.v11i2.2103 quality of water in relation of all hydrological properties. Analysis of physicochemical properties of water present limnological conditions and contributes in environment protection process (Verma et al., 2012, Patel and Parikh, 2013, Uddin et al., 2016). A number of workers have done their works on physicochemical parameters of pond water (Paul and Mukherjee, 2006, Chaurasia and Pandey, 2007, Kiran, 2010, Mondal et al., 2011, Prasath et al., 2013, Bhavimani and Puttaiah, 2014, Swarnakar and Choubey, 2016, Kumari and Singh, 2016, Harmoko and Krisnawati, 2019). The present investigation will gather adequate baseline data to explain contemporary limnological circumstances of the pond as there are many researchers who monitored physicochemical parameters of various ponds at Patna district but almost no work has been reported regarding water quality of Sanjay Gandhi Jaivik Udyan pond. Paul and Sanyal, (2017) studied the seasonal variation of physicochemical characteristics of Sanjay Gandhi Jaivik Udyan pond, Patna (Bihar) India for one year. The objective of the present study was to observe the monthly variation in the pond for the period based on the investigations of two consecutive years i.e. from May, 2016 - April, 2018 
which offers detail perspectives about the ideal levels of parameters necessitated to maintain biodiversity and productivity level of the pond for commercial fisheries.

\section{MATERIALS AND METHODS}

Study area: This study was conducted on the pond situated at Sanjay Gandhi Jaivik Udhyan Patna, Bihar, India. This pond receives large amount of allochthonous matter (animal sewage, detergents, soaps, run off etc.) from the zoo campus. Three sampling stations were selected in the pond to get an idea of overall situation of the pond. The geographical location of pond is $25.596513^{\circ} \mathrm{N}$ and $85.099304^{\circ} \mathrm{E}$. Climatic condition of Patna is tropical having three distinct season:winter (December to February), summer (March to June), monsoon (July to September), post- monsoon (October - November).

Sampling was done monthly for the period of two years from May 2016 to April 2018 using standard methods suggested in APHA, AWWA and WEF (2005). Water samples were collected during the early hours within 9.30 to 10.30 am from the three spots. Average values of the parameters were considered for evaluation. The physicochemical parameters including temperature (atmospheric and water), $\mathrm{pH}$, transparency, specific conductivity, total solids (TS), total dissolve solids (TDS), total suspended solids (TSS), dissolved oxygen (DO), free carbon dioxide, total alkalinity, total hardness, chloride, inorganic phosphorus, nitrate, sodium, potassium, Biological Oxygen Demand (BOD), Chemical Oxygen Demand (COD) of the pond were studied.

Surface water temperature was measured on the sampling spots using a celsius-thermometer graduated up to $110^{\circ} \mathrm{C}$ (accuracy $0.1^{\circ} \mathrm{C}$ ). Transparency was measured using Secchi disc. Specific conductivity was measured by conductivity meter (Ecotester EC low). Turbidity was recorded using Nephelometer (Systronics digital nephelo-turbidity meter, Model:132). Total solids, total dissolved solids and total suspended solids were estimated using gravimetric method.

$\mathrm{pH}$ of the water sample was measured using $\mathrm{pH}$ meter (Waterproof pH tester ${ }^{\circledR} 10$, Eutech instruments). Dissolved oxygen was estimated using standard Winkler's titration method. Total alkalinity, chloride, total hardness, calcium and magnesium hardness, were analysed by titration method. Biochemical Oxygen Demand was measured using five days incubation process. Chemical Oxygen Demand was determined using condensation, digestion and titration method. Nitrate and inorganic phosphorous were measured using UV-Vis Spectrophotometer (Model:104 Systronics Ltd., India). Sodium and potassium can be determined accurately by flame photometer (Systronics flame photometer, Model:128). All observations were

\section{taken into triplicates.}

Statistical analysis: All the computations and calculations of statistical analysis were performed by the methods of Zar (2007), MS excel 2007 and statistical software SPSS Ver 21.0.

\section{RESULTS AND DISCUSSION}

The result of monthly variation in physicochemical properties of surface water of Sanjay Gandhi Jaivik Udhyan pond are average values of three sites of the pond which depicts the overall situation.

Water temperature: Water temperature has a high influence on the quality of water. It accelerates or slow down the rate of the chemical reactions which takes place in aquatic water bodies (Paul and Mukherjee, 2006, Wilde, 2006). Water temperature was always found lower than the atmospheric temperature. Water temperature showed significant positive correlation with atmospheric temperature $(r=0.975)$ at the Sanjay Gandhi Jaivik Udyan pond water, which indicates water temperature is affected by atmospheric temperature (Table 1). Monthly water temperatures of Sanjay Gandhi Jaivik Udhyan pond recorded from May 2016 to April 2018 indicate that variation of temperature was seasonal, as it rose in summer and fell in winter (Fig. 1). Mean water temperature of two years was found to be $24.225 \pm 1.26{ }^{\circ} \mathrm{C}$. The values of water temperature ranged from 12.8 $\pm 0.2{ }^{\circ} \mathrm{C}$ (in January, 18) to $32.6 \pm 0.24{ }^{\circ} \mathrm{C}$ (in June, 17) (Fig. 1). From the month of March to August gradual increase in water temperature was observed due to increase of solar radiation and analogously prolong day length. Likewise, a systematic decrease in incident sunlight and other climatic factors like cloud coverage explain fall in temperature from months of October (season) to February (winter) and form April onwards again the water temperature increased gradually.

Transparency: Transparency of water body signifies the depth up to which the light can penetrate. Transparency is highly variable and helps to determine the productive zone of water body. From May, 16 to April, 18, the maximum value of transparency recorded in winter season, December, 16 was $24.57 \pm 0.18 \mathrm{~cm}$ and minimum value of transparency recorded in monsoon season, July, 17 was $16.95 \pm 0.62$ (Fig 2). The mean value of transparency from May, 16 to April, 18 was 21.47 $\pm 0.46 \mathrm{~cm}$. Light penetration depends partly on the light flux but mainly on the optical properties of water. The reduced transparency during monsoon months was appeared to be associated with the presence of suspended inorganic substances such as silts and clay in large quantity, which began to settle down after the monsoon and transparency tended to increase through post monsoon and winter months; and finally water bodies, transparency usually decreases also during summer 


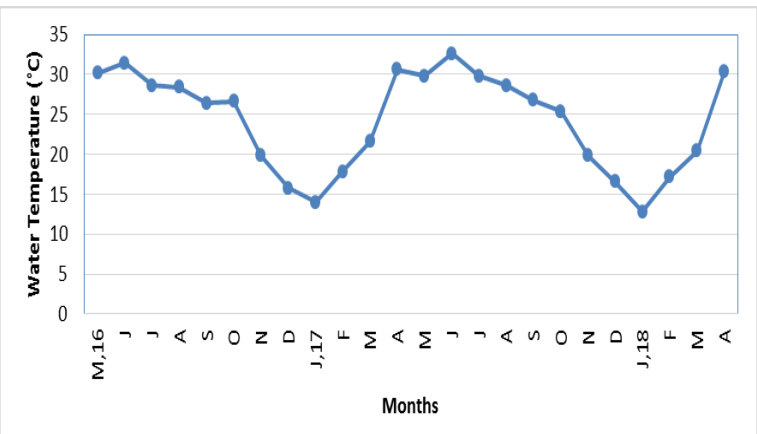

Fig. 1. Monthly variation of water temperature $\left({ }^{\circ} \mathrm{C}\right)$ of Sanjay Gandhi Jaivik Udhyan pond.

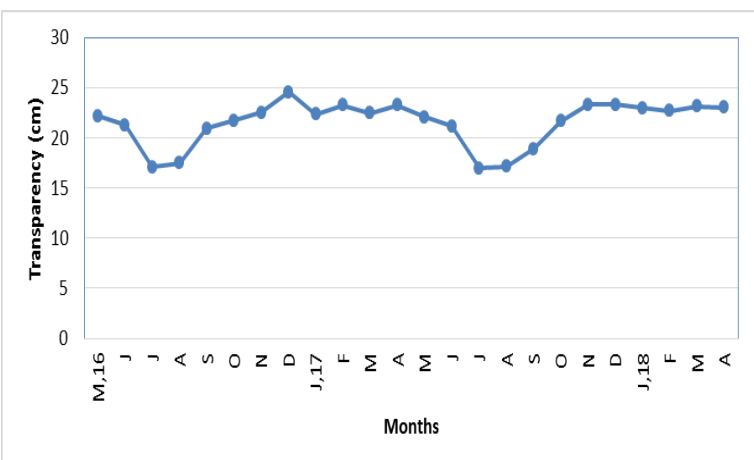

Fig. 2. Monthly variation of Transparency $(\mathrm{cm})$ of Sanjay Gandhi Jaivik Udhyan pond.

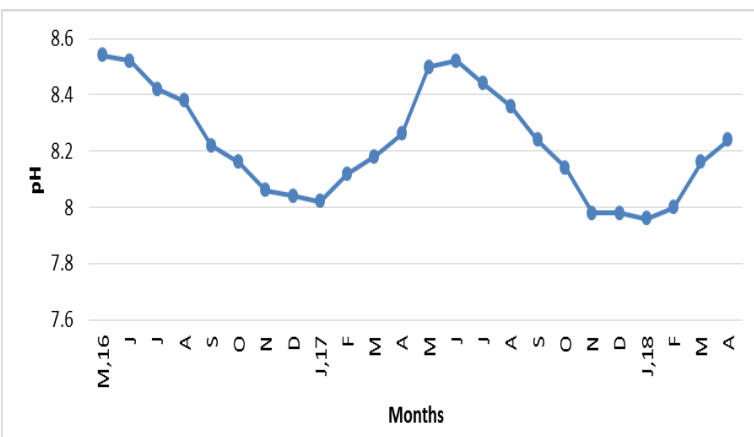

Fig. 5. Monthly variation of $\mathrm{pH}$ of Sanjay Gandhi Jaivik Udhyan pond.

months due to reduced water level and disturbances of the basin. (Ohol and Kamble, 2011) have also observed similar results in Ganesh Tank, Miraj, Sangli district of Maharastra. Transparency showed significant negative correlation with turbidity $(r=-0.935), \mathrm{pH}(r=-0.564)$, total dissolved solids $(r=-0.790)$, total suspended solids $(r=-0.605)$, total solids $(r=-0.935)$ (Table 1 ). Increase in concentration of total dissolved solids, total suspended solids, total solids and turbidity makes water opaque due to addition of clay, silt, and other organic matter thereby reducing the transparency.

Total solids: The total solids can be determined by adding up of suspended as well dissolved sol-

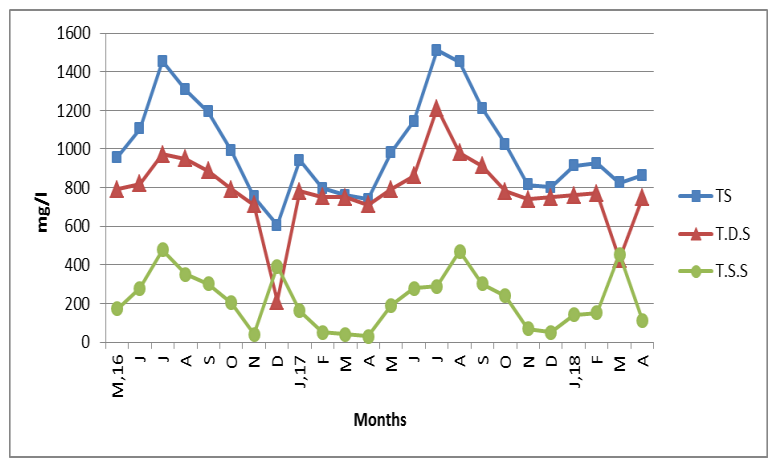

Fig. 3. Monthly variation of TS, TDS, TSS (mg/l) of Sanjay Gandhi Jaivik Udhyan pond.

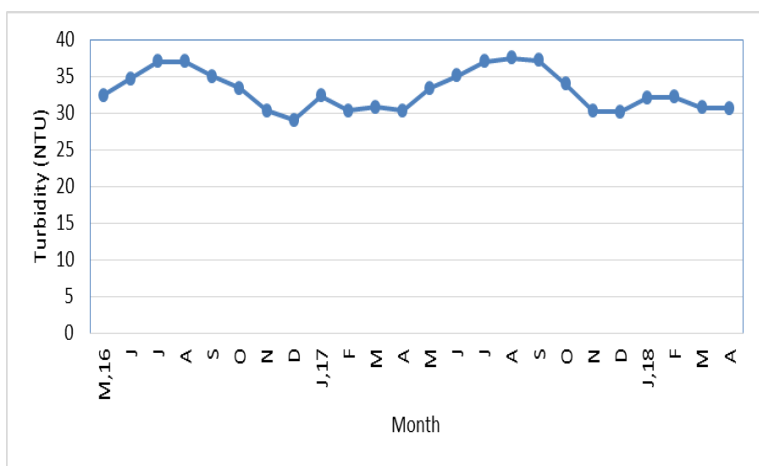

Fig. 4. Monthly variation of Turbidity (NTU) of Sanjay Gandhi Jaivik Udhyan pond. .

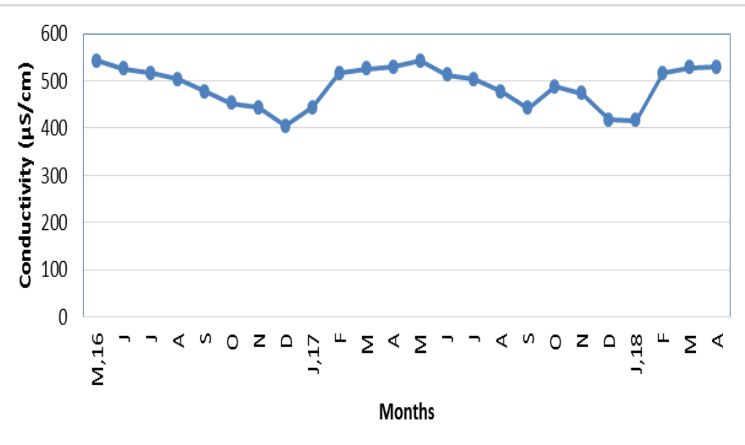

Fig. 6. Monthly variation of Conductivity $\left(\mu \mathrm{S} \mathrm{cm}^{-1}\right)$ of Sanjay Gandhi Jaivik Udhyan pond.

ids present in water (Qureshimatva et al, 2015). Increased concentration of TS lowers the transparency in water. TS in Sanjay Gandhi Jaivik Udhyan pond was recorded from May 2016 to April 2018 (Fig. 3). From May, 16 to April, 18, the lowest value of TS recorded during winter season in December, 16 was $604 \pm 2.25 \mathrm{mg} / \mathrm{l}$ and from the highest value of TS recorded during monsoon season in July, 17 was $1510.66 \pm 4.50 \mathrm{mg} / \mathrm{l}$ (Fig 3 ). Round the year average TS from May, 16 to April, 18 was $1002.944 \pm 50.414$. Total solids showed significant negative relation with transparency ( $r=-0.957$ ), and significant positive relation with total alkalinity $(r=0.667)$, inorganic phosphorus $(r=0.550)$, sodium $(r=0.530)$, total suspend- 
Sanyal, S. and Paul, D.K. / J. Appl. \& Nat. Sci. 11(2): 492- 502 (2019)

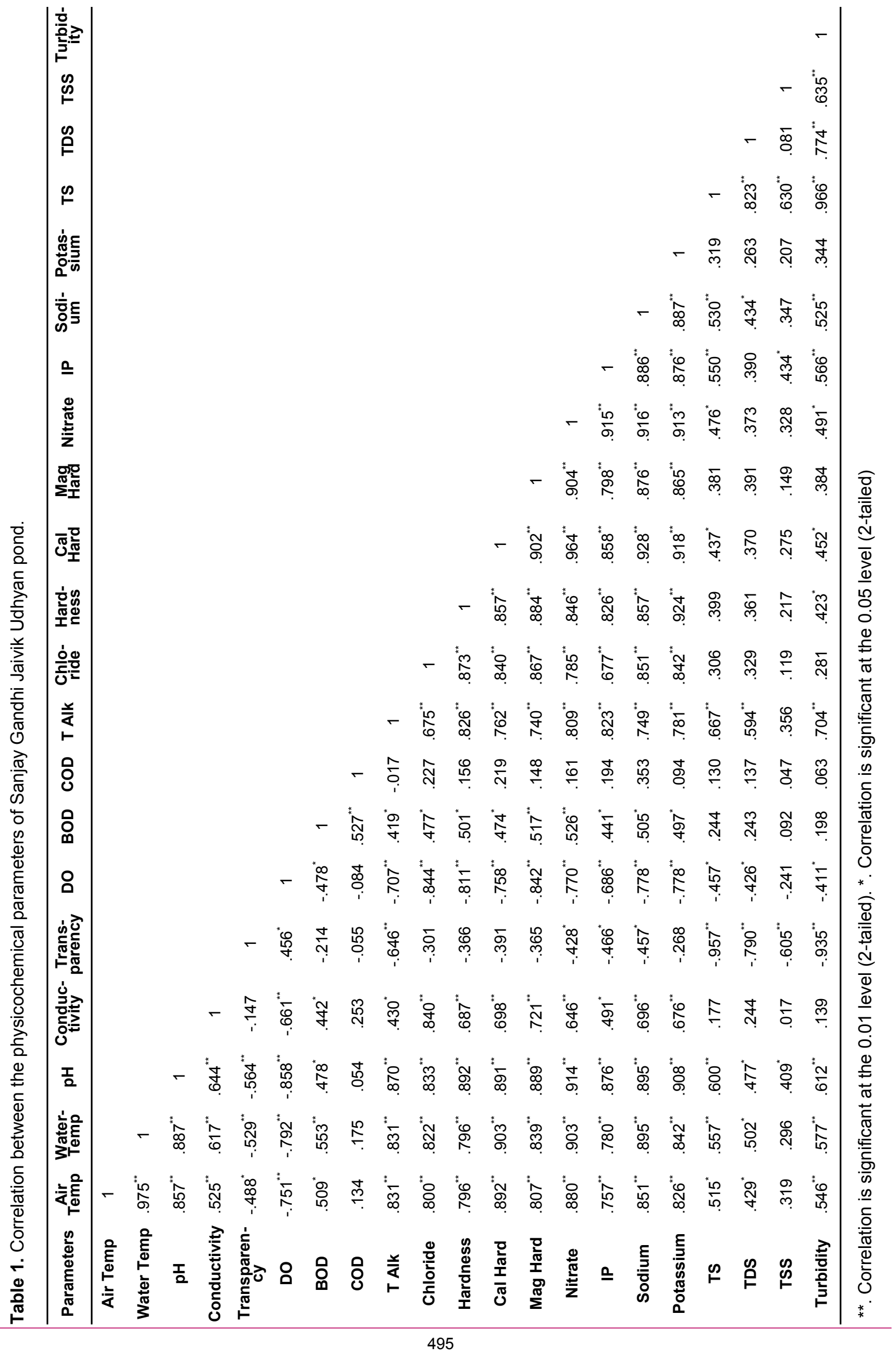


ed solids $(r=0.630)$, total dissolved solids $(r=$ $0.823)$, turbidity $(r=0.966)$ (Table 1$)$. Nutrient status of pond also increases with increasing TS.

Total dissolved solids: Water is often called the universal solvent. Large numbers of minerals, metals, organic matters, inorganic salts mainly calcium, magnesium, sodium, potassium, chlorides etc, (size: less than 2 microns) are dissolved in it (Charkhabi and Sakizadeh, 2006). TDS in drinking water originate from sewage and wastewater. Total dissolved solids showed significant positive relation with water temperature $(r=$ $0.502)$, total alkalinity $(r=0.594)$, total solids $(r=$ $0.823)$, sodium $(r=0.434)$, turbidity $(r=0.774)$ (Table 1). The trend of monthly variation of total dissolved solids (TDS) of Sanjay Gandhi Jaivik Udhyan pond was similar to the trend of monthly variation of TS. From May, 16 to April, 18, the lowest value of TDS recorded during winter season in December, 16 was $211.33 \pm 1.437 \mathrm{mg} / \mathrm{l}$ and, the highest value of TDS recorded during monsoon season in July, 17 was $1210 \pm 0.89 \mathrm{mg} / \mathrm{l}$ (Fig 3). Round the year average TDS from May, 16 to April, 18 was $785.91 \pm 37.79$. It may be due to the addition of the allochthonous matter in the pond.

Total suspended solids: Total suspended solids (TSS) are the solids which drift or float in the water. It can include sediment, sand, clay, silt, gravel, planktons etc. These solids are too light to get settled at the bottom of the pond. Bathing in water with high TSS is not suitable Gay and Proop, (1993). Total dissolved solids showed significant positive relation with water temperature $(r=$ $0.502)$, total alkalinity $(r=0.594)$, total solids $(r=$ $0.823)$, turbidity $(r=0.774)$ (Table 1$)$. Monthly variation in total suspended solids (TSS) of Sanjay Gandhi Jaivik Udhyan pond was recorded from May 2016 to April 2018 (Figure 3). From May, 16 to April, 18, the highest monthly value of TSS recorded during monsoon season in July, 16 was $478.33 \pm 2.11 \mathrm{mg} / \mathrm{l}$ the lowest value of TSS recorded during summer season in April, 16 was $31 \pm$ $1.18 \mathrm{mg} / \mathrm{l}$ (Fig 3). Round the year average TSS from May, 16 to April, 18 was $219.027 \pm 29.0390$ $\mathrm{mg} / \mathrm{l}$.

Turbidity: Turbidity is the amount suspended matter present in any aquatic body, because of which the aquatic body losses its transparency. Higher the concentration of total suspended solids, higher will be the turbidity. Suspended solids include silt, clay, sand, planktons, waste water etc. The mean value of turbidity was found to be $33.027 \pm 0.5529$ NTU which ranged between $37.46 \pm 0.22$ NTU to $29 \pm 0.44$ NTU where lowest concentration of turbidity was recorded during summer season in April, 16 and the highest value of turbidity recorded during monsoon season in August, 17 (Fig 4). In monsoon season the concentration of TDS show increasing trend because huge amount of allochthonous matter from the

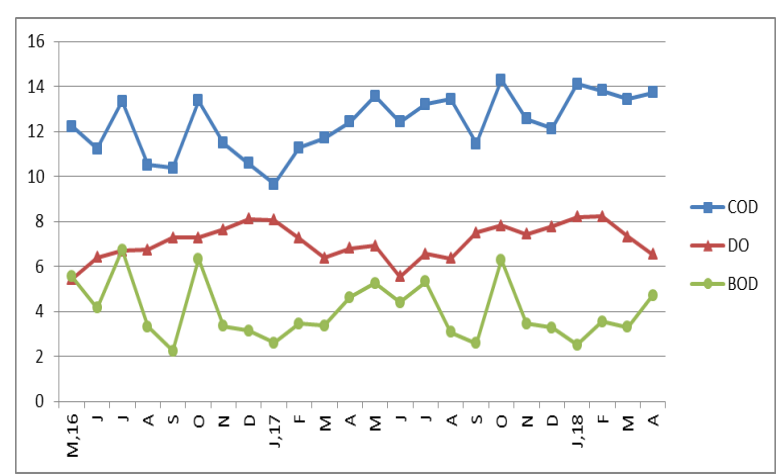

Fig. 7. Monthly variation of $D O, B O D, C O D(\mathrm{mg} / \mathrm{l})$ of Sanjay Gandhi Jaivik Udhyan pond.

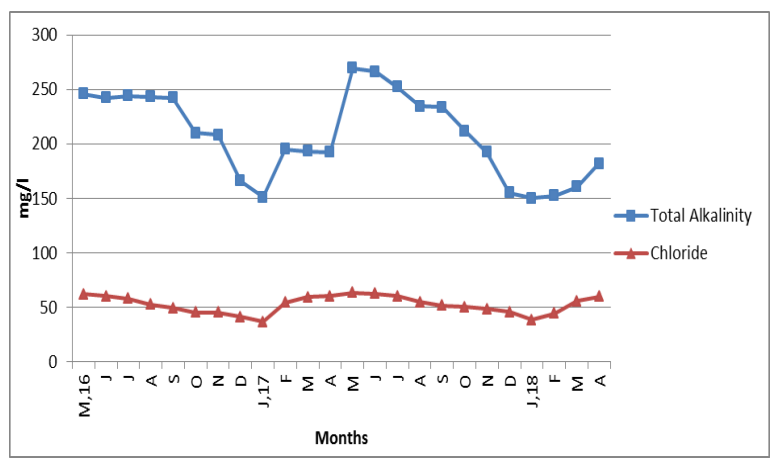

Fig. 8. Monthly variation of total Alkalinity and chloride (mg/l) of Sanjay Gandhi Jaivik Udhyan pond.

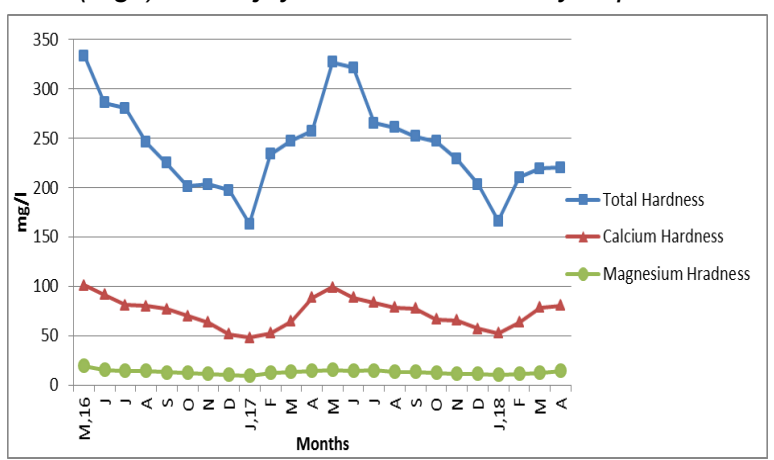

Fig. 9. Monthly variation of total, calcium and magnesium hardness (mg/l) of Sanjay Gandhi Jaivik Udhyan pond.

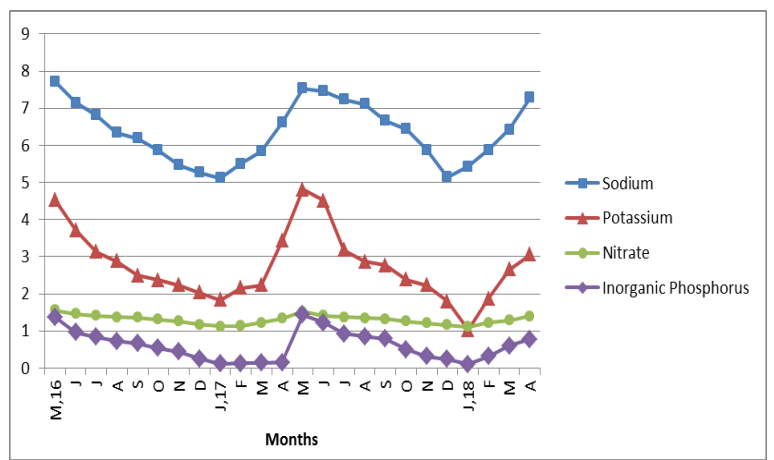

Fig. 10. Monthly variation of nitrate, inorganic phosphorus, sodium and potassium ( $\mathrm{mg} / \mathrm{l})$ of Sanjay Gandhi Jaivik Udhyan pond. 
surface run-off are added in the pond water (Srivastava and Srivastava, 2011). From postmonsoon to winter season the value of turbidity declined because suspended matter started to settle down gradually after monsoon season. Turbidity showed significant positive relation with water temperature $(r=0.577), \mathrm{pH}(r=0.612)$, total alkalinity $(r=0.704)$, inorganic phosphorus $(r=$ $0.566)$, sodium $(r=0.525)$, total solids $(r=$ $0.966)$, total dissolved solids $(r=0.774)$, total suspended solids ( $r=0.635$ ) (Table 1$)$. More the suspended particles present, more will be the turbidity. This confirms the correlation between turbidity and total suspended solids. As concentration of turbidity is inversely proportional to clarity of water, more the turbidity, lesser the clarity of water or transparency.

pH: The $\mathrm{pH}$ is a measure of concentration of $\mathrm{H}^{+}$ ions in water, therefore it helps to determine acidity as well as alkalinity of water. $\mathrm{pH}$ is important limiting factor for aquatic organisms. The $\mathrm{pH}$ of pond water of was slightly alkaline (Fig 5). $\mathrm{pH}$ increased in winter months but decreased in summer months. From May, 16 to April, 18, the highest value of $\mathrm{pH}$ recorded in May, 16 was $8.54 \pm$ 0.0245 (summer) and lowest value of $\mathrm{pH}$ recorded in January, 17 was $7.96 \pm 0.0245$ (winter) (Fig 5). The average value of $\mathrm{pH}$ of two year study was $8.22 \pm 0.0392$. Most of the ponds and lakes of India are alkaline in nature (Sharma et al.,1984). Slight seasonal changes indicate well acid-base buffering capacity (Hagens et al. 2015). $\mathrm{pH}$ is associated with photosynthesis in water. High $\mathrm{pH}$ value signifies high photosynthetic activity as $\mathrm{pH}$ value increases with the extraction of carbon dioxide from water. It also promote the growth of algae. Similar to this study, higher level of $\mathrm{pH}$ was observed during the summer season by (Jakher and Rawat, 2003) in tropical lake of Jodhpur, Rajasthan, India. pH showed high significant positive correlation with conductivity $(r=0.644)$, total alkalinity $(r=0.870)$, chloride $(r=0.833)$, hardness $(r=0.892)$, sodium $(r=0.895)$, potassium $(r=$ $0.908)$, nitrate $(r=0.914)$, inorganic phosphorus $(r$ $=0.870$ ) (Table 1) which indicate discharge of waste water into the pond.

Conductivity: Conductivity of water signifies about its extent to pass electric current. It depends on various factors like valence of ions, concentration and mobility of ions, temperature etc. (University of Virginia Physics Department, 2003, Qureshimatva, 2015, Paul et al., 2015). Conductivity in water is due to ionization of dissolved inorganic solids. Pure water has zero conductivity. In the present study, the maximum value of conductivity recorded during summer season in May, 17 was $542 \pm 11.57 \mu \mathrm{S} \mathrm{cm}^{-1}$ and minimum value of conductivity recorded during winter season in December, 16 was $404 \pm 2.44 \mu \mathrm{S} \mathrm{cm}^{-1}$ (Fig. 6). The average value conductivity from May, 16 to April,
18 was $488.75 \pm 8.73 \mu \mathrm{S} \mathrm{cm}^{-} 1$. Conductivity showed high positive correlation with $\mathrm{pH}(\mathrm{r}$ $=.644)$, chloride $(r=.840)$, hardness $(r=0.687)$, calcium hardness $(r=0.698)$, magnesium hardness $(r=0.728)$, sodium $(r=0.697)$, potassium $(r$ $=.676)$ (Table 1). Seasonal variations of conductivity may be due to the variation in average temperatures.

Dissolved Oxygen (DO): Dissolved oxygen (DO) is the amount of free, molecular oxygen dissolved in water. The value of $\mathrm{DO}$ revel the health of whole aquatic ecosystem, even when details of other physical, chemical and biological parameters are not accessible. Main sources of dissolved oxygen in water bodies include air (by the process of diffusion) and phytoplanktons (by the process of photosynthesis). Degree of pollution was determined as dissolved oxygen (DO) in Sanjay Gandhi Jaivik Udhyan pond from May 2016 to April 2018 (Fig 7). From May, 16 to April, 18, the minimum value of DO was observed during summer season in May, 16 was $5.426 \pm 0.13 \mathrm{mg} / \mathrm{l}$ and the highest value of DO recorded during winter season in January, 18 was $8.216 \pm 0.01 \mathrm{mg} / \mathrm{l}$ (Fig. 7). The average DO from May, 16 to April, 18 was $7.04 \pm 0.16 \mathrm{mg} / \mathrm{l}$ (Table 1). Dissolved Oxygen exhibit high negative correlation with water temperature $(r=-0.792), \mathrm{pH}(r=-0.858)$, chloride $(r=$ $-0.844)$, hardness $(r=-0.811)$, calcium hardness $(r$ $=-0.758)$, magnesium hardness $(r=-0.842)$, nitrate $(r=-0.770)$, inorganic phosphorus $(r=$ $0.686)$, sodium ( $r=-0.778$ ) (Table 1$)$. Water temperature is a physical parameter which significantly regulates the Dissolved oxygen. Strong negative correlation between water temperature and dissolved oxygen was found because oxygen gets dissolved better in colder temperature than warmer water. As a result in winter season, when the water temperature was low, the value of dissolved oxygen was observed high and in summer season, due to high temperature, the value of dissolved-oxygen was observed low.

Biological Oxygen Demand (BOD): Biochemical oxygen demand (BOD) is a measure of the amount of oxygen needed by microorganisms to decompose the organic matter. BOD was analyzed on monthly basis between May 2016 to April 2018 (Fig 7). The average BOD from May, 16 to April, 18 was found to be $12.34 \pm 0.26 \mathrm{mg} / \mathrm{l}$. The range of $B O D$ was recorded as $6.73 \pm 0.074 \mathrm{mg} / \mathrm{l}$ to $2.24 \pm 0.035 \mathrm{mg} / \mathrm{l}$ (maximum value was observed during monsoon season in July, 16 and minimum value was recorded during postmonsoon season in September, 16) (Fig 7). The highest demand of oxygen in the water was recorded during monsoon season was due addition of waste water. The observed values of BOD suggest that this pond is moderately polluted. Yadav et al., (2013) also found similar results in fresh water pond of Orai, U.P., Central India as ob- 
served in the present study. Biological Oxygen Demand showed significant positive correlation with water temperature $(r=0.553)$, chemical oxygen demand $(r=0.527)$, hardness $(r=0.501)$, calcium hardness $(r=0.526)$, magnesium hardness $(r=0.512)$, sodium $(r=0.505)$ and negative correlation with dissolved oxygen $(r=-0.478)$ (Table 1). Bacteria present in the water consumed the dissolved oxygen to degrade the organic matter present in water. When concentration of biological oxygen demand is high, the concentration of dissolved oxygen levels decreases, this proves the strong negative correlation between biological oxygen demand and dissolved oxygen

Chemical Oxygen Demand (COD): The Chemical Oxygen Demand (COD) in a water body measures the amount of oxygen needed to oxidise the inorganic chemicals present. COD showed significant positive correlation with Biological Oxygen Demand $(r=.0527)$. The average concentration of COD from May, 16 to April, 18 was found to be $12.34 \pm 0.267 \mathrm{mg} / \mathrm{l}$ (Table 1). The value of COD ranged from $9.656 \pm 0.049 \mathrm{mg} / \mathrm{l}$ to $14.27 \pm 0.114 \mathrm{mg} / \mathrm{l}$ (minimum value was observed during winter season in January, 17 and maximum value was observed during post monsoon season in October, 17) (Fig 7). (Nag and Gupta, 2014) also found similar results in various ponds located in Santiniketan, West Bengal, India as observed in the present study.

Total alkalinity: As per (Bheemappa et al., 2015), "total alkalinity is a measure of the substances in water that have acid-neutralizing ability". There are various factors that affects total alkalinity these include hydroxide ions, bicarbonates, carbonates etc. (Lodh et al., 2014, and Paul et al., 2010,2014 . The variation of total alkalinity was seasonal, as it rose in summer and fell in winter (Fig 8). The average total alkalinity from May, 16 to April, 18 was found to be $211.11 \pm 7.94 \mathrm{mg} / \mathrm{l}$. The range of total alkalinity was recorded as $150.267 \pm 0.13 \mathrm{mg} / \mathrm{l}$ to $269.36 \pm 0.157 \mathrm{mg} / \mathrm{l}$ (minimum value in winter season, January, 18 and maximum value in summer season, May, 17) (Fig 8). During summer season, because of high degradation of plants, organisms and organic waste, concentration of carbonate and bicarbonate thereby alkalinity also increased. (Mondal et al., 2011) has also observed a similar result in a pond of Burdwan Municipality, Burdwan, West Bengal, India. Total alkalinity exhibit significant positive correlation with $\mathrm{pH}(r=0.870)$, chloride $(r=$ $0.6750)$, conductivity $(r=0.644)$, total hardness $(r$ $=0.826)$, calcium hardness $(r=0.762)$, magnesium hardness $(r=0.742)$, nitrate $(r=0.809)$, inorganic phosphorus $(r=0.823)$, sodium $(r=0.749)$, potassium $(r=0.781)$, total solids $(r=0.667)$, total dissolved solids $(r=0.594)$, turbidity $(r=0.704)$ (Table 1). Total alkalinity showed strong positive correlation with total hardness, calcium hardness, magnesium hardness and specific conductivity, as because increase of salt content in water is responsible to increase permanent hardness and conductivity. This again confirms that the electrical conductance was probably due to calcium and magnesium salts.

Chloride: Chloride ions in water bodies are ubiquitous in nature. In freshwater it is found in low concentration, that may be due to natural or anthropogenic causes. Water softeners to remove calcium and magnesium ions, sewage contamination, and fertilizers like potassium chloride are primarily responsible for addition of chloride ions in water. Low concentration of chloride does no harm but at higher concentration osmoregulation in aquatic organisms gets disturb. In the present study mean value of chloride from May, 16 to April, 18, was $52.50 \pm 1.63 \mathrm{mg} / \mathrm{l}$. The lowest value of chloride was recorded in winter season, in the month of January, 17. It was found to be $36.59 \pm$ $1.35 \mathrm{mg} / \mathrm{l}$ and the highest value of chloride recorded in summer season, May, 17 was $63.51 \pm 0.13$ $\mathrm{mg} / \mathrm{l}$ (Fig 8). Low concentration of chloride might be due to absence of agricultural activities near the sampling sites and absence of rocky soils (Costa et al., 2015, Richter and Netto, 1991). The highest value of chloride content was reported in summer season. This is mainly due to run-off containing sewage from the campus of the Sanjay Gandhi Zoological park and evaporation of water. Similar results were also observed by (Qureshimatva et al., 2015) who studied Water Quality Index (WQI) of Chandlodia Lake, Ahmedabad, Gujrat, India. Chloride showed significant positive correlation with conductivity $(r=0.840, P)$, total alkalinity $(r=0.675)$, hardness $(r=0.873)$, calcium hardness $(r=0.840)$, magnesium hardness $(r=0.867)$, nitrate $(r=0.785)$, sodium $(r=$ $0.851)$, potassium $(r=0.842)$ (Table 1$)$. Chloride ion is generally present as salts of sodium, potassium, calcium. This explain its strong relationship with conductivity and ions such as sodium, potassium and calcium.

Total Hardness, Calcium Hardness and Magnesium Hardness: Calcium and magnesium ions are main responsible factors for hardness. It also caused by iron, aluminium, zinc, manganese, barium and strontium, but due to their small concentrations they do not significantly contribute to the total hardness. In this study the mean total hardness of Sanjay Gandhi Jaivik Udhyan pond was found to be $241.347 \pm 9.29$ (Fig 9). From May, 16 to April, 18, the maximum value was recorded during winter season in January, 17 was $333.33 \pm$ $2.581 \mathrm{mg} / \mathrm{l}$ and the minimum value of total hardness was recorded during summer season in May, 16 was $163 \pm 1.18 \mathrm{mg} / \mathrm{l}$ (Fig 9). High concentration of total hardness in summer season may be due to the regular addition of sewage of animals of the zoo and detergents and soaps used by the 
visitors. Low concentration of total hardness in winter season is due to minimum concentration of carbonates and bicarbonates of calcium which shows is due to the less pollution. (Patil and Tijare, 2001) have observed similar results in Godchiroli Lake, India. Hardness showed significant positive correlation with conductivity $(r=0.687)$, biological oxygen demand $(r=0.501)$, total alkalinity $(r=0.826)$, chloride $(r=0.873)$, calcium hardness $(r=0.857)$, magnesium hardness $(r=$ $0.884)$, nitrate $(r=0.846)$, inorganic phosphorus $(r$ $=0.826)$, sodium $(r=0.857)$, potassium $(r=$ 0.924 ) (Table 1). The total hardness shows strong correlation coefficient with calcium and magnesium hardness in the water because the two main cations that make water hard are calcium $\left(\mathrm{Ca}_{2}{ }^{+}\right)$ and magnesium $\left(\mathrm{Mg}_{2}{ }^{+}\right)$.

Calcium and magnesium ions contribute to bone and scale formation in fish. Calcium helps in active regulation of osmotic pressure in the fluids in aquatic organisms. It maintains accurate levels of salts in aquatic organisms for usual function of heart, kidney, muscle and nerve. (Prasath et al., 2013 and Lalitha et al., 2004). Deficiency of calcium can cause reproductive problems in animals. In this study variation in calcium hardness of Sanjay Gandhi Jaivik Udhyan pond was recorded from May 2016 to April 2018 (Fig 9). The mean value of calcium hardness was found to be 73.27 $\pm 3.08 \mathrm{mg} / \mathrm{l}$ which ranged between $48.07 \pm 0.020$ $\mathrm{mg} / \mathrm{l}$ to $101.2 \pm 0.089 \mathrm{mg} / \mathrm{l}$ where lowest concentration of calcium hardness was recorded during winter season in January, 18 and the highest value of calcium hardness recorded during summer season in May, 17 (Fig 9). Monthly variation in magnesium hardness of Sanjay Gandhi Jaivik Udhyan pond was recorded from May 2016 to April 2018 (Fig 9). The mean value of magnesium hardness was found to be $13.06 \pm 5.12 \mathrm{mg} / \mathrm{l}$ which ranged between $9.26 \pm 0.093 \mathrm{mg} / \mathrm{l}$ to $19.13 \pm$ $0.068 \mathrm{mg} / \mathrm{l}$ where lowest value of magnesium hardness was recorded during summer season in May, 16 and the highest value of magnesium hardness recorded during summer season in January, 17 (Fig 9). Aquatic animals can tolerate wide range of calcium hardness concentrations (Wurts, 2015). Calcium Hardness showed significant positive correlation with total hardness $(r=0.857)$ and magnesium hardness $(r=0.902)$, calcium hardness $(r=0.857)$ (Table 1$)$.

Nitrate: Inorganic nitrogen is important for the growth of plants and animals, but excessive concentration of nitrate can cause adverse health effects in aquatic organisms and speed up the growth of algae (Tank and Chippa, 2013). Monthly variation in nitrate of Sanjay Gandhi Jaivik Udhyan pond was recorded from May 2016 to April 2018 (Fig10). The average nitrate from May, 16 to April, 18 was found to be $1.30 \pm 0.02$. From May, 16 to April, 18 , the highest value of nitrate record- ed during summer season in May, 16 was $1.56 \pm$ $0.004 \mathrm{mg} / \mathrm{l}$ and the lowest value of nitrate recorded during winter season in January, 18 was $1.11 \pm$ $0.0044 \mathrm{mg} / \mathrm{l}$ (Fig10). Higher concentration may be due to influx of runoff from the zoo campus containing animal sewage. Many research shows highest value of nitrogen is associated with pollution of animal origin (Hill, 2005). High nitrate value causes algal bloom while nitrate at low level leads to increased lipid content in algae and in turn affect the water ecosystem. In the present investigation nitrate showed a bit lower value than what observed by Gayathri et al., (2013) in Nalluguddda Lake, Bangalore. Nitrate showed significant positive relation with $\mathrm{pH}(r=0.914)$, conductivity $(r=$ $0.646)$, biological oxygen demand $(r=0.526)$, total alkalinity $(r=0.809)$, chloride $(r=0.785)$, hardness $(r=0.846)$, inorganic phosphorus $(r=0.915)$, sodium ( $r=0.916)$, potassium $(r=0.913)$ (Table 1). Nitrates and phosphates accelerate the growth of aquatic plant and algae. Early growth leads to early death which increases the amount of organic waste in water, which promotes the bacterial decomposition, because of this biological oxygen demand increases.

Inorganic phosphorus: Phosphorous in freshwater is predominantly present in inorganic forms. The greatest sources are synthetic detergents, human waste and fertilizers. The higher concentration of phosphorous, therefore, is representative of pollution. In this study the mean inorganic phosphorus of Sanjay Gandhi Jaivik Udhyan pond was found to be $0.60 \pm 0.08$ (Fig 10). From May, 16 to April, 18, highest value of inorganic phosphorus recorded during summer season in May, 17 was $1.43 \pm 0.0078 \mathrm{mg} / \mathrm{l}$ and the lowest value of inorganic phosphorus recorded during winter season in January, 18 was $0.105 \pm 0.0006$ mg/l (Fig 10). Inorganic phosphorus showed significant positive relation with $\mathrm{pH}(r=0.876)$ total alkalinity $(r=$ $0.823)$, hardness $(r=0.826)$, calcium hardness $(r$ $=0.858)$, magnesium hardness $(r=0.798)$, nitrate $(r=0.915), \quad$ sodium $(r=0.886)$, potassium $(r=$ $0.876)$, total solids $(r=0.550)$, turbidity $(r=0.556)$ (Table 1). (Golder and Chattopadhyay, 2016) in a tropical lake of West Bengal and (Lodh et al., 2014) in ancient lakes of Udaipur City, Tripura, India have also observed similar results.

Sodium: Sodium is natural constituent of any aquatic body. But due to addition of pollution sources such as precipitation run off, soap solution and detergent from the compound of Sanjay Gandhi Biological park leads to rise in sodium level in the pond. The variation of sodium was seasonal, as it rose in summer and fell in winter (Fig 10). The average value of sodium from May, 16 to April, 18 was found to be $6.35 \pm 0.166 \mathrm{mg} / \mathrm{l}$. The range of sodium was recorded as $5.123 \pm$ $0.065 \mathrm{mg} / \mathrm{l}$ to $7.726 \pm 0.025 \mathrm{mg} / \mathrm{l}$ (lowest value in winter season, January, 17 and highest value in 
summer season, May, 16) (Fig 10). This is mainly due to influx of waste water from the compound of the biological park. Another reason for the highest value of sodium during this season may be attributed to the fact of reduction in the volume of water of pond due to the process of evaporation. The low concentration of sodium observed in January due to the bioaccumulation by living organisms. Similar observation was also found by (Umerfaruq and Solanki, 2015) in Bibi Lake, Ahmedabad, Gujarat, India. Sodium showed significant positive relation with $\mathrm{pH}(r=0.895)$, conductivity $(r=0.696)$, biological oxygen demand $(r=$ $0.505)$, total alkalinity $(r=0.749)$, chloride $(r=$ $0.851)$, hardness $(r=0.857)$, calcium hardness $(r$ $=0.928)$, magnesium hardness $(r=0.876)$, nitrate $(r=0.916)$, potassium $(r=0.887)$, total solids $(r$ $=0.530)$, turbidity $(r=0.525)$ (Table 1$)$. Sodium is strongly correlated with nitrite. This means that most of the sodium may be present as nitrate form (Baudisch, 1921).

Potassium: Potassium is an essential element for both aquatic plants and animal as both surface and ground water bodies contains it APHA, AWWA, WEF, (2005). Potassium maintains the osmotic pressure in the cells of aquatic organisms. Excessive level of potassium restrains the uptake of micronutrients by aquatic plants Cochrane and Cochrane, (2009). Potassium showed significant positive relation with $\mathrm{pH}(r=$ $0.908)$, conductivity $(r=0.676)$, total alkalinity $(r=$ $0.781)$, chloride $(r=0.842)$, hardness $(r=0.924)$, nitrate $(r=0.913)$, inorganic phosphorus $(r=$ $0.876)$, sodium ( $r=0.887$ ) (Table 1$)$. High organic matter content in pond water and alkaline $\mathrm{pH}$ values maintain the moderate concentration of potassium in pond water Sandhya and Benarjee, (2016). Monthly variation in potassium of Sanjay Gandhi Jaivik Udhyan pond was recorded from May 2016 to April 2018 (Fig10). From May, 16 to April, 18, the highest value of potassium recorded during summer season in May, 17 was $4.81 \pm$ $0.215 \mathrm{mg} / \mathrm{l}$ the lowest value of potassium recorded during winter season in January, 18 was $1.03 \pm$ $0.85 \mathrm{mg} / \mathrm{l}$ (Fig 10). The average value of potassium from May, 16 to April, 18 was recorded as $2.75 \pm 0.19 \mathrm{mg} / \mathrm{l}$. Similar observation was found by Multu and Kurnaz (2018) in Celtek pond, located in north of Sivas province on the southern slopes of the mountain Celtek, Turkey. At lower concentration potassium is not harmful but at higher concentration potassium can do severe damage to the water quality (Talling, 2010).

\section{Conclusion}

In conclusion, the present study, on water quality parameters at Sanjay Gandhi Jaivik Udhyan, Patna showed significant positive correlation between $\mathrm{pH}$, conductivity, total alkalinity, chloride, hardness, sodium, potassium, nitrate, inorganic phos- phorus. Some parameters also exhibited strong negative correlation with other parameter. DO exhibited high negative correlation with water temperature, $\mathrm{pH}$, chloride, total hardness, nitrate, inorganic phosphorus, sodium, another negative correlation was observed between transparency and turbidity, $\mathrm{pH}$, total dissolved solids, and total solids. Influx of organic and inorganic material from the biological park enhanced the concentration of total solids, turbidity etc. which reduce the transparency of water. It is therefore necessary to maintain a good pond water quality as per BIS standards as it will help in farming of fishes, that will require manpower, ultimately leading to employment of skilled personnel. Other ways to improve the quality of pond can be stoppage of the influx of sewage water as well as proper management of pet and animal waste.

\section{ACKNOWLEDGEMENTS}

The authors are thankful to Prof. (Dr.) R. K. Sinha and Prof. P. Nath the then HODs and Prof. (Dr.) Arbind Kumar, Head, Department of Zoology, Patna University for proving necessary laboratory facilities. Authors also express their gratitude to the Director, Sanjay Gandhi Jaivik Udyan, Patna for providing permission and cooperation to work there.

\section{REFERENCES}

1. APHA, AWWA and WEF (2005). Standard Methods for the Examinations of Water and Wastewater. A joint publication of the American Public Health Association (APHA), The American Water Works Association (AWWA), and the Water Environment Federation (WEF). (21st Ed). 1368.

2. Bano, Z., Chauhan, R., and Bhat, N.A. (2016). A study of seasonal physicochemical parameters in River Narmada. Journal of chemical, biological and physical sciences. 6(1), 10-17.

3. Barai, S.R. and Kumar, S. (2012). Evaluation of the physicochemical characteristics of river Varuna at Varanasi, India. Journal of Environmental Biology. 34, 259-265.

4. Baudisch, 0. (1921). The mechanism of reduction of nitrates and nitrites in processes of assimilation. Journal of Biological Chemistry. 48:489-502.

5. Beemappa, K., Nandini, N., Kumar. M.V., and Raghavendra, M. (2015). Temporal Variation in water quality parameters of Bandematta Lake -Peri Urban area of Bengaluru, Karnataka, India. International Journal of Advanced Research. 3(7),1283-1291.

6. Bhavimani, H., and Puttaiah, E.T. (2014). Fish culture and physico-chemical characteristics of Madikoppa Pond, Dharwad Tq/Dist, Karnatak. Hydrology. Current Research. 5,162.

7. Charkhabi, A.H., and Sakizadeh, M. (2006). Assessment of spatial variation of water quality parameters in the most polluted branch of the Anzali Wetland, Northern Iran, Polish. Journal of Environmental Studies, 15(3), 395-403.

8. Chaurasia M., and Pandey, G. C. (2007). Study of Physico-chemical characteristics of some water pond 
of Ayodhya-faizabad. Indian Journal of Environmental Protection. 27(11), 1019-1023.

9. Cochrane, T.T., and Cochrane, T,A. (2009). Differences in the way potassium chloride and sucrose solution effect osmotic potential of significance to stomata aperture modulation. Plant Physiology and Biochemistry. 47(3), 205-209. Doi: 10.1016/ j.plaphy.2008.11.006.

10. Costa, J.S., Braga, F.S., Almeida, S.S.M.S., Ramos, R.S., Brito, D.C., Cunha, A.C., and Santos, C.B.R. (2015). Physicochemical Characterization of Water Quality - Lagoa dos Índios in Macapá, Brazil. American Chemical Science Journal. 5(2),122-134.

11.Deshmukh, B.S. (2012). Hydrobiological study of river Pravara in Ahmednagar district (Maharashtra), Bionano Frontier, Eco Revolution 2012 Colombo, 89$92 \quad$ File:///C:/Users/S.\%20Sanyal/Downloads/ Alkalinity_and_Hardness_in_Production_Ponds $\% 20$ (1).pdf

12.Gay and Proop 1993. Aspects of River Pollution, Butterworths Scientific Publication, London.

13.Gayathri, S., Latha, N., and Mohan, M.R. (2013). Impact of physicochemical characteristics on phytoplankton diversity of Nalluguddda Lake, Bangalore. Journal of Academia and Industrial Research 2,349352.

14.Golder, D., and Chattopadhay, S. (2016). Interrelation between physico-chemical characteristics of a tropical lake and their impact of biodiversity of plants. Journal of Environmental Biology. 37,1281-1289.

15.Hagens, M., Slomp, C. P., Meysman F. J. R., Seitaj D. Harlay J. and Middelburg, J. J (2015). Biogeochemical processes and buffering capacity concurrently affect acidification in a seasonally hypoxic coastal marine basin. Biogeosciences. 12, 15611583.

16. Harmako, and Krishnawati Y. (2019). The quality of aur lake from Indonesia based on microalga bioindicator. Pollution Research. 38(1),33-37.

17. http://galileo.phys.virginia.edu/education/outreach/ 8thgradesol/TempSolubility.htm

18.Hill, D.D., Owens, W.E., Tchoounwou, P.B. (2005). Impact of animal waste application on runoff water quality in field experimental plots. Internaltional Journal of environmental research and public health. 2(2), 314-21.

19.Jakher, G.R., and Rawat, M. (2003). Studies on physico-chemical parameters of a tropical lake, Jodhpur, Rajasthan, India. Journal of Aquatic Biology 18(2),79-83.

20.Kiran, B.R. (2010). Physicochemical characteristics of fish ponds of Bhadra project at Karnataka. RASAYAN Journal Chemistry. 3,671-676.

21.Kumar, M, and Padhy, P.K. (2015). Environmental perspectives of pond ecosystems: Global Issues, Services and Indian Scenarios. Current World Environment. 10,848-867.

22.Kumari, N., and Singh SP (2016). Ecological parameters variation of a fish pond of the village Fatehabad, Muzaffarpur of Bihar. Recent Life Science Mirror. 5,19-22.

23.Lalitha, S., Kalaivani, D., Selvameena, R., Santhi, R., and Barani, A. (2004). Assay on quality of water samples from medical college area in Thanjavur. Indian Journal of Environmental Protection. 24,925930.

24.Lodh, R., Paul, R., Karmakar, B., and Das, M.K. (2014). Physicochemical studies of water quality with special reference to ancient lakes of Udaipur City, Tripura, India. International Journal of Scientific and Research Publications. 4,1-9.

25.Majumder, S., and Dutta, T.K. (2014). Studies on seasonal variations in physic-chemical parameters in Bankura segment of the Dwarakeshwar River (W.B) India, International Journal of Advanced Research. 2 (3), 877-881.

26.Mohan V.C., Sharma K.K. and Sharma A. (2013) .Limnological profile of Chenani Hydroelectric Reservoir, its connecting channel and River Tawi in Udhampur district of JandK, India. International Research Journal of Biological Sciences. 2(3),76-79.

27.Mondal, N.K., Datta, J.K., and Banerjee, A. (2011). Pond alkalinity: A study in Burdwan Municipality, Burdwan, West Bengal, India. International Journal of Environmental Sciences. 1,1718-1724.

28.Mutlu, E., and Kurnaz, A. (2018). Assessment of physicochemical parameters and heavy metal pollution in Celtek pond water. Indian Journal of Geo Marine Sciences. 47(06), 1185-1192.

29.Nag, A., and Gupta, H. (2014). Physicochemical analysis of some water ponds in and around Santiniketan, West Bengal, India. International Journal of Environmental Sciences. 5,676-682.

30.Ohol, R.R., and Kamble, (2011). Study of physicochemical Characteristics of Ganesh Tank, Miraj, district Sangli, Maharastra. Nature Environment and Pollution Technology, 10,81-83.

31.Patel, V. and Parikh, P. (2013). Assessment of seasonal variation in water quality of River Mini, at Sindhrot, Vadodara. International Journal of Environmental Sciences. 5, 1424-1436

32.Patil, D.B. and Tijare, R.V. (2001). Studies on Water Quality of Godchiroli Lake. Pollution Research. 20,257-259

33.Paul, D.K. (2010) Limnological investigation of the river Ganga and its tributaries in and around Patna. The Biosphere 2,82 -83.

34.Paul, D.K., and Sanyal, S. (2017). Assessment of seasonal variation of physicochemical characteristics of Sanjay Gandhi Jaivik Udyan pond, Patna (Bihar) India. Journal of Patna Science College. 5,91-107.

35.Paul, D.K., and Mukherjee, P. (2006). A preliminary study of physicochemical characteristic of a perennial pond. Journal of Haematology and Ecotoxicology. 1,49-56.

36.Paul, D.K., Sanyal, S., Swarna, S., and Kumari, R. (2015). Impact of saraswati idol immersion on the water quality of Ganga river at Patna (Bihar), India. Journal of Patna Science College, 3, 147-162.

37.Paul, D.K., Syed, Z. H., and Kumari, A. (2014). The effect of town effluents on some physic chemical properties of Ganga river at Krishna Ghat, Patna Bihar. Journal of Patna Science College, 2,117-185.

38.Prasath, B.B., Nandakumar, R., Kumar, S.D., Ananth, S., Devi, S., Jayalakshmi, T., Raju, P., Thiyagarajan, M., and Santhanam, P. (2013). Seasonal variations in physico-chemical characteristics of pond and groundwater of Tiruchirapalli, India. Journal of Environmental Biology. 34,529-537.

39.Qureshimatva, U.M., Maurya, R.R., Gamit, S.B., Patel, R.D., and Solanki, H.A. (2015). Determination of Physico-chemical parameters and Water Quality Index (WQI) of Chandlodia Lake, Ahmedabad, Gujrat, India. Journal of Haematology and Ecotoxicology. 5,288 
40.Richter, C.A., and Netto, J.M.A. (1991). Water treatment - updated technology. Sao Paulo: Edgard Blucher;. Portuguese.

41.Sandhya, K., and Benarjee, G. (2016). Physicochemical properties of some selected fresh water fish ponds in relation to fish production in Warangal area. International Journal of plant, animal and environmental sciences. 4(6). http://dx.doi.org/10.21276/ ijpaes.

42.Sharma, M.S., Sharma, L.L., and Durve, V.S. (1984). Eutrophication of Lake Pichhola in Udaipur, Rajasthan. Pollution Research. 3(2),39-44.

43.Smitha, P.G., Byrappa, K., and Ranaswamy, S.N. (2007). Physicochemical characteristic of water samples of Bantwal Taluk, South Western Karnataka, India. Journal of Environmental Biology. 28,591-595.

44.Srivastava, A., and Srivastava, S. (2011). Assessment of physicochemical properties and sewage pollution indicator bacteria in surface water of River Gomti in Uttar Pradesh. International Journal of Environmental Sciences. 2,325-336.

45.Swarnakar, A.K., and Choubay, S. (2016). Testing And Analysis of pond water in Raipur city, Chhattisgarh, India. International Journal of Science and Research. 5,1962-1965.

46. Talling, J.F. (2010). Potassium - a non-limiting nutrient in fresh waters? Freshwater reviews. 3,97-104. Doi:10.1608/FRJ-3.2.1

47.Tank, S.K. and Chippa, R.C. (2013). Analysis of Water Quality of Halena Block in Bharatpur Area.
International Journal of Scientific and Research Publications. 3

48.Uddin, Md. G., Md. Moniruzzaman., Muhammad, AlA,H,. Md. A, Ha. and Khan, M. (2016). Seasonal variation of physicochemical properties of water in the Buriganga River, Bangladesh. World Applied Sciences Journal 34 (1),24-34.

49.Umerfaruq, M.Q., and Solanki, H.A. (2015). Physicochemical Parameters of Water in Bibi Lake, Ahmedabad, Gujarat, India. Journal of pollution effects and control 3,134. doi:10.4172/2375-4397.1000134.

50.University of Virginia Physics Department.(2003). Temperature Effects on Solubility. Retrieved January, 03, 2019 from

51.Verma, P.U., Purohit, A.R., and Patel, N.J. (2012). Chanlodia Lake located in Ahmedabad, Gujrat. International Journal of Engineering Research and Applications. 2,1600-1610.

52.Wilde, F. (2006). Temperature 6.1. In USGS Field Manual. Retrieved December, 26, 2018 from http:// water.usgs.gov/owq/FieldManual/

Chapter6/6.1_ver2.pdf.

53.Wurts, W.A. (2015). Article in World Aquaculture. Alkalinity and Hardness in production ponds. Retrieved February, 02, 2019 from

54.Yadav, P., Yadav, V.K., Yadav, A.K., and Khare, P.K. (2013). Physico-Chemical Characteristics of a Fresh Water Pond of Orai, U. P., Central India. Octa Journal of Biosciences. 1, 177-184.

55.Zar, J.H. (2007). Biostatistical Analysis. $4^{\text {th }}$ Edition. Pearsons's Education. Delhi. India. 663. 